\title{
Valuation of Environmental Services of Catchment Forests Within Baubau Wonco Watershed
}

\author{
Safril Kasim ${ }^{1}$, Aminuddin Mane Kandari ${ }^{2}$, La Ode Midi ${ }^{3}$, Anita Indriasari ${ }^{4}$ \\ ${ }^{1}$ Spesifications Agroforestry, Department of Environmental Science, Faculty of Forestry and Environmental Science, Halu Oleo University, \\ Southeast Sulawesi, Indonesia \\ ${ }^{2}$ Spesifications Agroclimatology, Department of Environmental Science, Faculty of Forestry and Environmental Science, Halu Oleo University, \\ Southeast Sulawesi, Indonesia \\ ${ }^{3}$ Spesifications Agrohidrology, Department of Environmental Science, Faculty of Forestry and Environmental Science, Halu Oleo University, \\ Southeast Sulawesi, Indonesia \\ ${ }^{4}$ Spesifications Agriculture of Economic and Social, Department of Environmental Science, Faculty of Forestry and Environmental Science, \\ Halu Oleo University, Southeast Sulawesi, Indonesia
}

\section{Email address:}

safrilkasim1970@gmail.com (S. Kasim),manekandaria@yahoo.com (A. M. Kandari), laodemidi@gmail.com (L. O. Midi), anitayulardhi@gmail.com (A. Indriasari)

\section{To cite this article:}

Safril Kasim, Aminuddin Mane Kandari, La Ode Midi, Anita Indriasari. Valuation of Environmental Services of Catchment Forests Within Baubau Wonco Watershed. Agriculture, Forestry and Fisheries. Vol. 4, No. 6, 2015, pp. 275-283. doi: 10.11648/j.aff.20150406.17

\begin{abstract}
Catchment forests cover a total of 2.750, 11 Ha. This is about 31, 85\% of the total area of Baubau Wonco watershed. This forested land provides both tangible and intangible benefits of which some are perceived as environmental services. However, it has encountered high rate of deforestation and forests degradation [7]. A well managed catchment forests can bring about advantages to a wide range of stakeholders, normally far away from the forests in the form of water for domestic use, agriculture, industry, and preventing from flooding, erosion and landslide hazards. To this view, it is a logical assumption that these various stakeholders who are mostly living in the downstream area should provide costs for a good forest management as incentives to the local community who mostly occupy the upstream area. Therefore, the need of a model that regulates the upstream and downstream mechanism should be explored. The research is planned to be conducted for two years. The first year research has been carried out from July to October 2015. The study employed various methods of data analysis. Those are as follow: (i) Hedonic Price is used for estimating economic value of water for domestic and industrial use; (ii) Productivity approach used for analyzing economic value of water for agricultural use; (iii) Willingness to Pay (WTP) is used for analyzing economic value of catchment forests to preventing from erosion, flooding and landslide hazards. The results of the first year research show that the total volume of water domestic consumption reachs $6.163 .488,50 \mathrm{~m}^{3}$ year $^{-1}$, which is used by 18.950 households with the economic value obtains of Rp. 40.062.668.750 year ${ }^{-1}$, while the economic value of water for agricultural use achieves Rp. 30.199.167/ha year ${ }^{-1}$. This research will be continued to the second year study to (i) estimate the economic value of industrial water, (ii) to analyze the Total Economic Value of hydrological environmental services provided by catchment forests of the watershed area, and (iii) to develop a model that can facilitate downstream-upstream mechanism of a payment for the hydrological environmental services.
\end{abstract}

Keywords: Hydrological-Environmental Services, Valuation, Domestic Use, Agricultural Use, Industrial Use, Erosion, Flood and Landslide Hazard Control

\section{Introduction}

Catchment forests offer both tangible and intangible benefits of which some are perceived as environmental services. However, catchment forests in Baubau Wonco Watershed area have faced serious degradation due to infrastructure development, housing, mining activities, agricultural use and forest encroachment and illegal lodging activities. Forested land use changes within the watershed have brought about changes in river discharged, an increase of erosion hazard and sedimentation [7]. Integrated watershed management planning has been made as a guideline of water, 
land and forest resources management within the watershed area. However, there are still obstacles in the implementation phase including lack of funds [5].

Catchment forests within watershed area have significant roles to increase availability and quality of water, to minimize the rate of erosion and sedimentation as well as to decrease a potential risk of landslide hazard. These hydrological environmental services provided by the catchment forests are maintained by local communities. While the beneficiaries of these are vary and can be ranged from local actors to international stakeholders. To this point, there is a new believe proposed by neo-market natural resources economists that new methods and institutional frameworks need to be developed for facilitating a downstream-upstream incentive model or mechanism [17]. It is therefore, financial incentives have to be made available by international, national, regional and local stakeholders to compensate environmental services of the watershed area that are for long generation maintained by local people, To some extents, these are refer to as Payment for Environtal Services (PES). A downstrean and upstream model can become a policy umbrella to facilitate the PES as financial compensations to the local actors who have conducted forest conservation efforts. This financial subsidy can be used to sustain their livelihoods and to increase their capacity to managing natural forests. The PES can be well applied if Total Economic Value (TEV) of hydrological environmental services of the cathment forests is well determined. Furthermore, a need of institutional set-up is crucial. This study attempts to analyze the TEV and to develop an institutional model that can be implemented through downstream and upstream incentive mechanism.

An economic valuation of hydrological environmental services is a method to determine economic value as provided by cathcment forests. This is becoming more substantial since the need of clean water increase significantly over years. An increase of water demands seems to be parralel with an increase of population numbers. Nowadays, water resource is becoming a rare commodity because almost all activities of human beings need a clean water. A water resource is needed for domestic, agricultural, and industrial uses, etc. Moreover, a water resource can also be used for source of electricty. However, results of some researchs stated that within a last hundred years, number of world populations have increased three times. A ratio between water need and population numbers has led to water scarcity due to less of water supply in comparation with water demand.

Water scarcity has emerged as a global problem, especially in summer session. Water availabity that is increase and even overflows during the rainy/winter session has a low quality and if uncontrolable can lead to flooding whereas during the summer season water is becoming scarce commodity, thus water is getting more expensive and has high economic value. An increase trend of economic value of water resource from time to time needs to be systematically explored in order to get reliable data and information that can be used to determine incentive for PES.
The development of hydrological environmental services through a downstream-upstream model as one alternative to support local community efforts to conserving watershed area. Economic valuation of hydrological environmental services can describe a relationship between economic and environmental aspects that are needed on decision making process to determining alternative uses of water and proper water conservation programs in the future.

Baubau Wonco Watershed constitutes a total of 9999, $75 \mathrm{Ha}$ in which consists of four Sub Watersheds namely: Wamoose Sub Watershed, Wasamparona, Sigari and Wancuawu. This watershed streams administeratively over two regencies: Baubau City and Buton Regency of which about 8.634,01 Ha is located in Baubau City [5].

The Baubau Wonco Watershed has a strategic location which is the downstream area streams to the center of

Baubau city and has an outlet in the Baubau strain. With this strategic position, the watershed has ecological, economic and social functions. Ecologically, Baubau Wonco Watershed has a significant role as a catchment forested area, to absorb and to stream rainy water to the outlet. Furthermore, catchment forest provide micro climate, oxygen supplies and carbon monooxyde absorber that is produced by industrial sectors, transportations and domestic sources. Besides, abundant and divers aquatic biota live in the river of Baubau Wonco Watershed.

The Baubau Wonco Watershed economically serves as agricultural land area for crop plantation and paddy field. Moreover, the downstream area that is located in the Central Business District of Baubau City has a great potency to be developed as an ecotourism destination.

Socially, the Baubau Wonco Watershed provides open space for the local community in which upstream-middle and downstream community has interacted to each other in doing their daily activities. This kind of social interaction that is using watershed area as media should be properly managed so that every actor can take benefits and conducts efforts to deal with the impacts resulted from watershed development programs. This Upstream-Downstream relationship can be seen, i.e. upstream community has to be aware that their activities in cultivating the upland area for agriculture or conserving forested land must bring about negative or positive impacts to the middle and downstream community. It is therefore, the need to establish a payment for environmental services by downstream community and other stakeholders is crucial. This is important to reenforce commitments of upstream community in order to protect catchment forested land and to implement agricultural practices that are in line with soil and water conservation principles. Besides, the funds will be very useful to saveguard their livelihood.

Based on description aboved, this research is intended to conduct economic valuation of hydrological environmental services of Baubau Wonco Watershed and to develop a proper model that can be implemented to facilitate the Upstream and Downstream Community as to provide Payment for Environmental Services. The logical framework of this research is presented in Figure 1. 


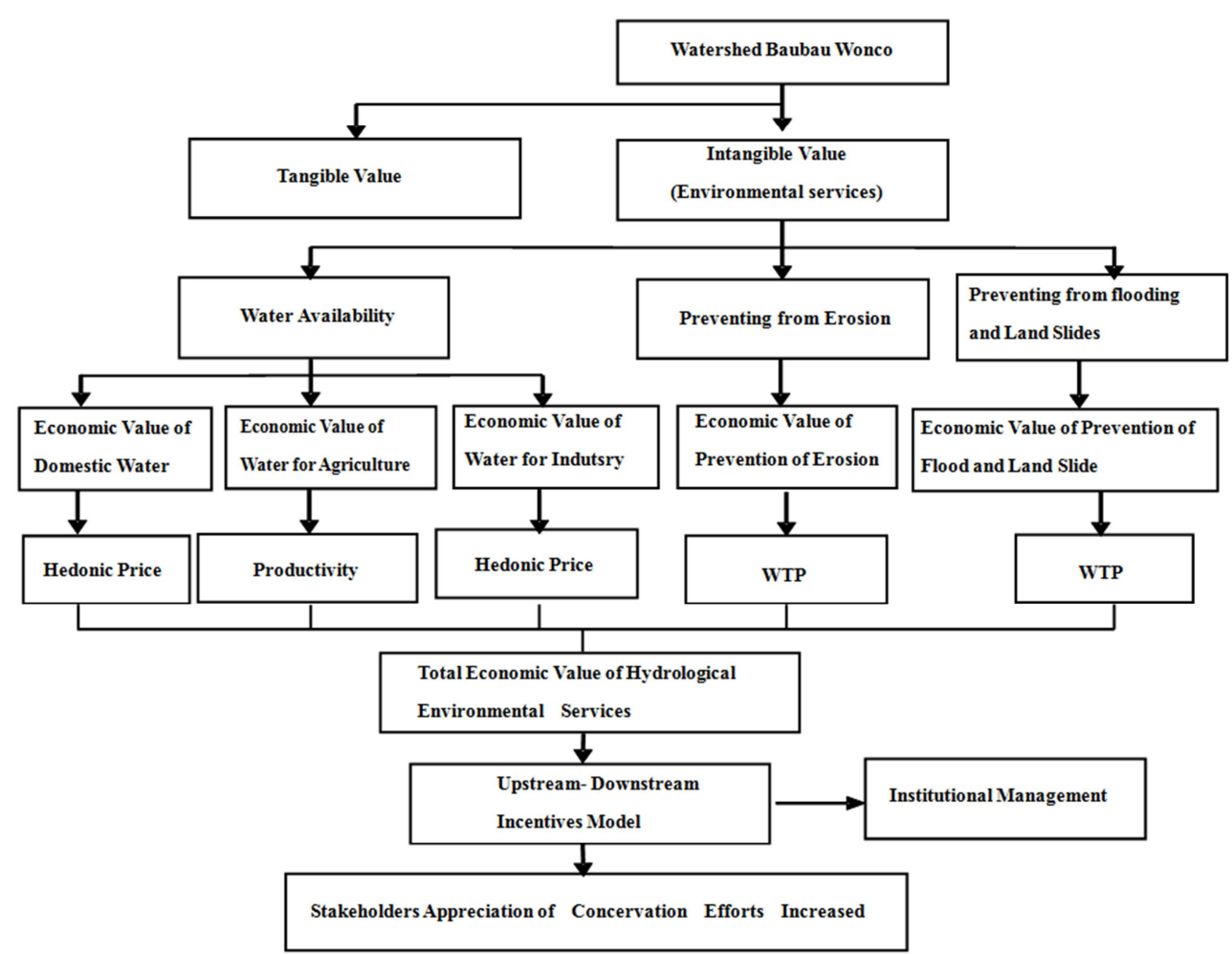

Figure 1. The Logical Framework to A Valuation of Hydrological Environmental Services of Catchment Forests Within Baubau WoncoWatershed.

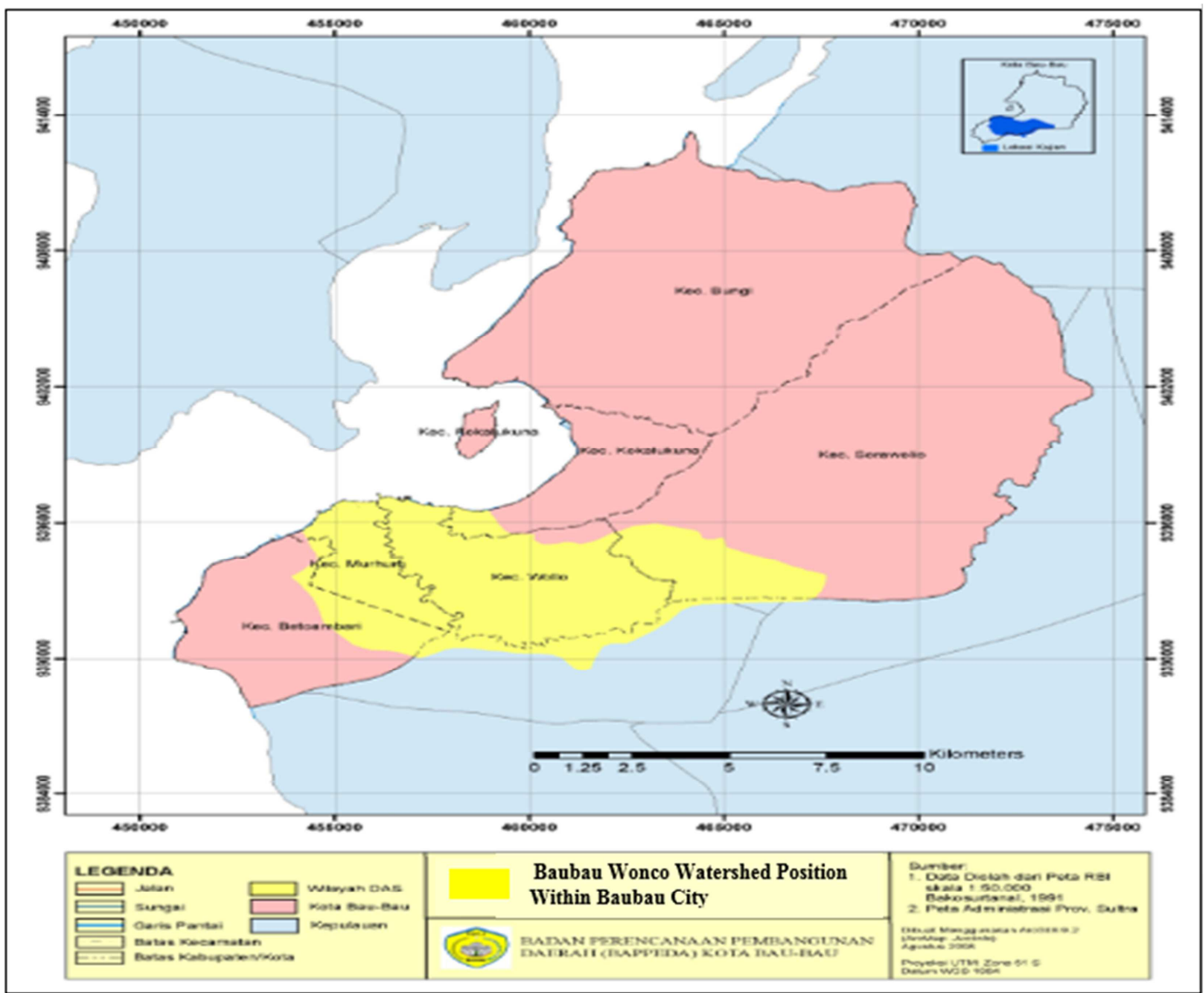

Figure 2. Map of Baubau Wonco Watershed Position Within Baubau City. 


\section{Study Area}

This study is conducted within Baubau Watershed area. Total area of Baubau Watershed is 9999, $75 \mathrm{Ha}$ and it consist of four subwatersheds namely Wamoose Subwatershed, Wasamporona, Sigari and Wancuawu., Baubau Watershed is administeratively located in two districts, Baubau City and Buton District, in which 8634,01 Ha is situated in Baubau City and 1365,74 ha in Buton District [5]. This watershed is geographically located in $5^{\circ} 27^{\prime} 8^{\prime \prime}$ and $5^{\circ} 32^{\prime} 33^{\prime \prime}$ South Latitude and $122^{\circ} 33^{\prime} 5^{\prime \prime}$ and $122^{\circ} 42^{\prime} 34^{\prime}$ East Longitude.

The soil types are dominated by litosol patch $(51,30 \%)$ and Mediteran Types (41,77\%), while Latosol only occupy 6,93 of total watershed land. The watershed area receives rainfall $1785,2 \mathrm{~mm}$ in average/year with 147 rainy days. The highest monthly averages of raifall happens in December $(272,00 \mathrm{~mm}$ with 20 rainy days) whereas the lowest occurs in September (9,5 $\mathrm{mm}$ with 2 rainy days) [11].

There are four subdistricts belong to Baubau City and two others belong to Buton Regency. For the purposes of this study, data collected is only to be carried out in the four subdistricts of Baubau City namely : Sorawolio, Wolio, Murhum and Betoambari. Map of Location of Baubau Wonco Watershed can be seen in Figure 2.

\section{Methodology}

The first year research has been carried out from July to October 2015. The study employs various methods in valuation of hydrological environmental services of the watershed, namely : Hedonic Price for estimating economic value of water for domestic and industrial use, productivity approach used for analyzing economic value of water for agricultural use, while Willingness to Pay (WTP) approach using for the valuation of cathcment forest reserves for preventing from erosion, flooding and landslide hazards. Primary data was collected through observation and deep interview with respondents in each sub district. This is included : (i) number of households who are using clean water for domestic and agricultural uses from the catchment forests of the Baubau Wonco Watershed, (ii) number of industries that are using clean water from the cathcment forests of the watershed, (iii) The water volumes that are consumpted for domestic, agricultural and industrial uses, (iv) Spended costs for water consumption, (v) Spended costs for agricultural activities (paddys field), (vi) Paddys Fields Total Areas, (vii) Paddys Field Production/Year, (viii) An intensity of Crop Season/Year.

Whereas secondary data was collected through documenting such sources of data as : reports of previous study, government documents, especially related to the government policies and statistical reports that are relevant with the purposes of the study.

Data analysis was carried out using such formula as :

(a) Total volume of water consumption for domestic use using a formula as follows :

$$
\text { TVDC }=\frac{W C \times 30}{n} \times \sum \text { population } \times 1 \text { year }
$$

Notes :

- TVDC = Total volume of Water Consumption for Domestic Use $\left(\mathrm{m}^{3}\right.$ year $\left.{ }^{-1}\right)$

- $\mathrm{WC}=$ Water Consumption for domestic use $\left(\mathrm{m}^{3} \mathrm{HH}^{-1}\right.$ day $^{-1}$ )

- $\mathrm{n}=$ Number of Respondents

(b) Clean Water Economic Value is determined based on Hedonic Price that has been decided by Local Government of Baubau City, which is used a formula as follows:

$$
\mathrm{EVDU}=\mathrm{TVWC} \times \mathrm{HP}
$$

Notes:

- $\mathrm{EVDU}=$ Economic Value of Clean Water for Domestic Use (Rp/Year)

- TVWC = Total volume of Water Consumption for Domestic Use (m3/year)

- $\mathrm{HP}=$ Hedonic Price $(\mathrm{Rp} / \mathrm{m} 3)$

(c) Economiv Value for Agriculture (Irrigated Paddy Field) is analyzed using a formula as follows :

$$
\text { EVAU }=\frac{E V T P-C}{X w}
$$

Notes:

- $\mathrm{EVAU}=$ Economic Value for Agriculture Used/Irrigated Paddy Field ( (Rp/Year)

- EVTP = Economic Value of Total Productivity $(\mathrm{Rp} / \mathrm{Season} /$ Year)

- $\mathrm{C}=$ Spended Costs (Rp/Season/Year)

- $\mathrm{Xw}=$ Volume of Water Consumption of Irrigation (m3/Second/Ha)

(d) Total volume of water consumption for industrial use using a formula as follows :

$$
\text { TVIC }=\frac{W C \times 30}{n} \times \sum \text { industries } \times 1 \text { year }
$$

Notes:

- TVIC = Total volume of Water Consumption for Industrial Use(m3/year)

- $\mathrm{WC}=$ Water Consumption for Industrial Use (m3/day)

- $\mathrm{n}=$ Number of Respondents

(e) Water Economic Value for Industrial Use is determined based on Hedonic Price that has been decided by Local Government of Baubau City, which using a formula as follows:

$$
\mathrm{EVIU}=\mathrm{TVWC} \times \mathrm{HP}
$$

Notes:

- $\mathrm{EVIU}=$ Economic Value of Clean Water for Industrial Use (Rp/year)

- TVWC = Total volume of Water Consumption for Industrial Use Use(m3/year) 
- $\mathrm{HP}=$ Hedonic Price $(\mathrm{Rp} / \mathrm{m} 3)$

(f) Economic Value of Catchment Forests for Preventing from erosion using a formula as follows :

$$
\mathrm{WTP}=\sum_{i=1}^{21} A W P i\left(\frac{n i}{N}\right) \times \text { Population }
$$

Notes:

- $\mathrm{AWPi}=$ An average of Willingness to Pay

- $\mathrm{ni}=\mathrm{A}$ number of respondents who are willing to pay for environmental services

- $\mathrm{N}=\mathrm{A}$ number of Samples

(g) Economic Value of Catchment Forests for Preventing Flooding and Landslide Hazards using the same formula as used to estimate economic valuation for preventing from erosion formula as follows :

$$
\mathrm{WTP}=\sum_{i=1}^{21} A W P i\left(\frac{n i}{N}\right) \times \text { Population }
$$

Notes:

- AWPi = An average of Willingness to Pay

- $\mathrm{ni}=\mathrm{A}$ number of respondents who are willing to pay environmental services

- $\mathrm{N}=$ A number of Samples

(h) Total Economic Value of Catchment Forests of Baubau Wonco Watershed is estimated using a formula as follows:

$$
\text { TEVES }=\text { EVDU }+ \text { EVAU }+ \text { EVIU }+ \text { EVPE }+ \text { EVPFL }
$$

Notes:

- TEVES = Total Economic Value (Rp/year)

- $\mathrm{EVDU}=$ Economic Value for Domestic Use (Rp/year)

- $E V A U=$ Economic Value for Agricultural Use (Rp/year)

- EVIU = Economic Value for Industrial Use (Rp/Year)

- $\mathrm{EVPE}=$ Economic Value for Preventing from Erosion $(\mathrm{Rp} /$ Year)

- $\mathrm{EVPFL}=$ Economic Value for Preventing from Flooding and Lanslides Hazards (Rp/Year)

\section{Result and Discussion}

\subsection{Characteristics of Baubau Wonco Watershed}

\subsubsection{Slope}

Slope is a basic element for analyzing and visualizing landform characteristics. It is important in studies of watershed units, landscape units, and morphometric measures [12];[13]. Slope combines with such other elements as soil texture, organic matters, existing types of vegetation, can be used to calculate runoff, forest inventory estimates, wild life habitat suitability and site analysis [16];[13]. Slope is a very crucial element for the Rate of Erosion Hazard Index.

A GIS analysis shows that topography classes vary ranges from $0-8 \%$ until $>45 \%$. The highest gradient is $>45 \%$ which occupie $2628,15 \mathrm{Ha}$, whereas the lowest is gradient $15-25 \%$ $392,98 \mathrm{Ha}$. Other topography classes present within the watershed land area are 0-8 \% 2548,58 Ha, 8 - $15 \% 2452,01$ Ha, 25 - $45 \%$ 612,29 Ha respectively [7].

\subsubsection{Soil}

Soil is an important elemen of watershed ecosystem, as it serves as an anchorage for plant and source of nutrients. Thus soil is the fundamental raw material for plant growth. The knowledge of soil resources is essential for proper watershed development and planning.

Soil type analysis reveals that there are three types of soil : Litosol, Latosol and Mediteran. Litosol type administeratively spread over in Bukit Wolio Indah Village, Kadolokatapi, Kadolomoko, Lipu, Melai and Waborobo, in which occupies 4429 Ha. Mediteran type occurs in Bungi, a part of Kadolokatapi, Kaisabu Baru and Karya Baru Villages which occupies 3606, 17 Ha. While Latosol spread over Bungi, a part of Kadolokatapi, a part of Karya Baru and Waborobo Villages with 3606, 17 Ha wide.

Towards the North Eastern Part and along the river side, soil depth is deep as compare to southern western part of Wolio Regency which is shallow one. It might be a result of undulating and a rugged topography. Moderate soil depth has been observed along eastern part of Sorawolio Regency and plain areas of Wolio Regency which is lying in between shallow and moderate suggesting treatment measures within a watershed [13].

\subsubsection{Land Use/Land Cover Analysis}

Knowledge of land use/land cover is important element for watershed planning and management and the way to better understanding of earth as an ecosystem. The term land cover relates to the type of feature present on the surface of the earth and land use relates to the human activity [13].

Land use/cover analysis shows that there are five types of land uses : (a) Forest; (b) Settlement; (c) Mixed Cropping; (d) Plantation/ Unirrigated agricultural field; and (e) Bushes. Forest area is widest land use which occupies $2.750,11 \mathrm{Ha}$ $(31,85 \%$ of the total watershed area), following by Settlement 2.068, $31 \mathrm{Ha}(23,96 \%)$, Mixed Cropping 1551, $85 \mathrm{Ha}$ $(17,97 \%)$, Plantation/ Unirrigated agricultural field 1.265, 21 Ha (14, 65\%), and Bushes 11,57 Ha (17, $97 \%$ ) respectively (Figure 3).

Baubau Watershed has served many functions and such functions as ecology and hydrology should be properly managed. This is due to significant roles of the watershed ecosystem as a buffer zone of Baubau City, a clean water reservoir' for the citizen and erotion and flooding controlling in the rainy season. As it located in the City area, this watershed has been threatened by development activities of Baubau City, thus land use could be rapidly changed in the future. It is therefore important to promote sustainable watershed management.

\subsubsection{Erosion Hazard Index}

Potential erosion within watershed area can be analyzed using USLE equation. The result of USLE analysis is used to calculate Erosion Hazard Index. This index can be used to indicate a spread of critical land within watershed area. Erotion Hazard Index is a prediction of maximum soil loss in a piece of land, if land management has no improvement for the long term uses and including calculation of solum of soil. 
Erosion Hazard Index analysis shows that more than $90 \%$ of Baubau Watershed Area can be categorized as critical lands which Erosion Hazard Index ranged from very high to middle rate of erosion. This is due to forested area within Bau-Bau Watershed that has functions as buffer zone and recharge area has been changed to be settlement, mixed garden and dry land crop. Furthermore, a few area of forested land has been changed to be waste land. This change has resulted in high runoff and erosion rate, and can potentially cause flooding in rainy season and a decrease of water availability in summer season [6]. Since erosion hazard can affect many actors both within and outside of watershed area, significant efforts should be done, including payment for environmental services as one of budget source to conduct forest conservation efforts at the implemetation phase of the watershed planning and management.

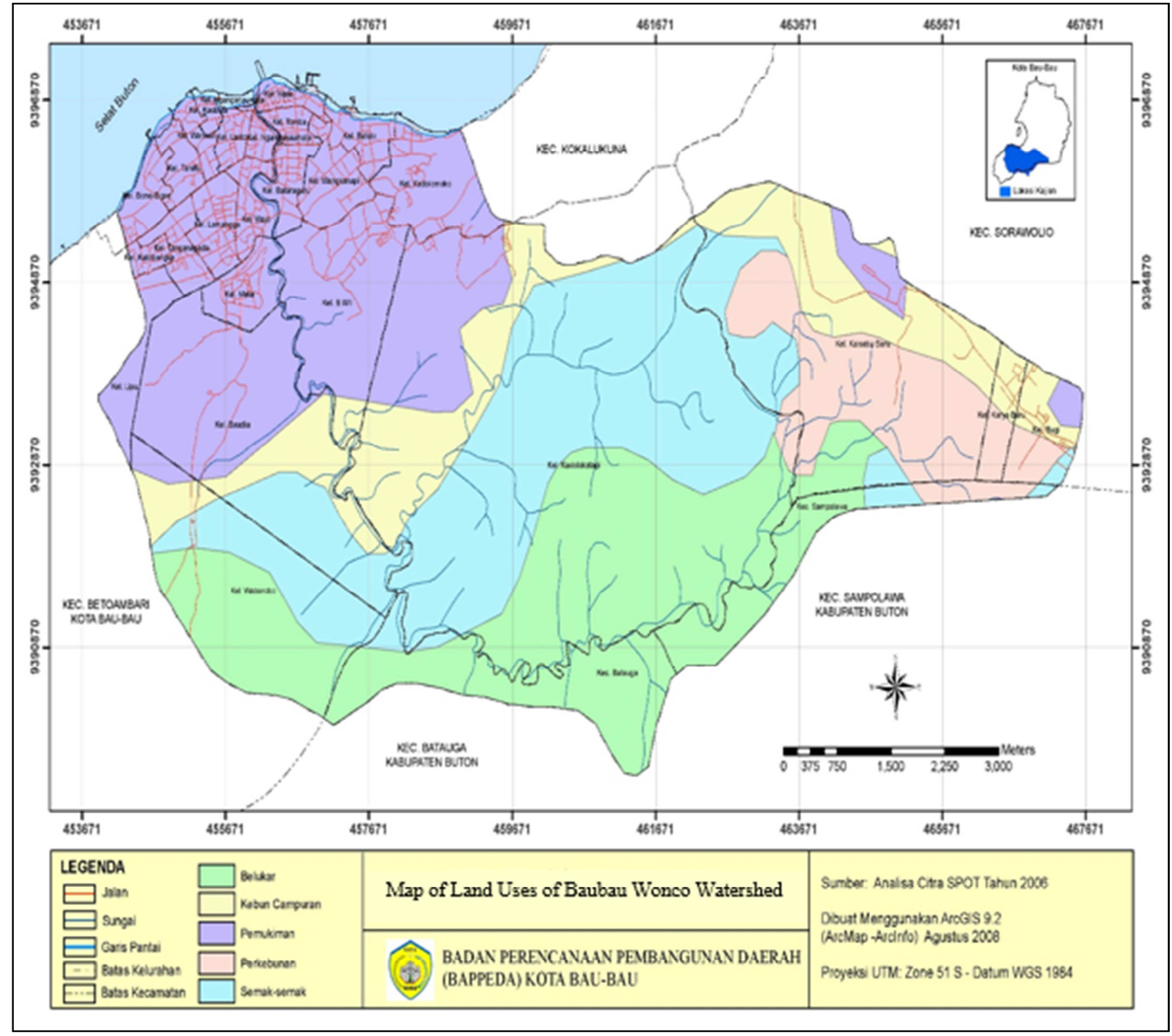

Figure 3. The Map of Land Uses of Baubau Wonco Watershed.

\subsubsection{Sedimentation}

Based on observation done in downstream of Baubau Watershed area, suspended load of sediment and sand has been found in ground floor of Baubau river. Sediment Delivery Ratio Analysis shows that total soil loss as a result of erosion which potentially deliver suspended sediment obtain 7.424,24 t year ${ }^{-1}$ [7].

\subsubsection{River Discharge Fluctuation}

River discharge analysis shows that maximum water dicharge is $10,245 \mathrm{~m}^{3} \mathrm{sec}^{-1}$ whereas minimum water discharged is $0,042 \mathrm{~m}^{3} \mathrm{sec}^{-1}$. This means that ratio between maximum and minimum water dicharged is 243,929 . This data indicated that overall, Baubau Watershed has been degraded because healhty watershed area has maximum and minimum ratio of water dicharge under 50 .

There are several substreams within Baubau Watershed area namely Wakonti, Wamose and Matantolindu River. Current measurement of those rivers which conducted in last summer season shows that river dicharge ranges from 0,2 s.d $0,3 \mathrm{~m}^{3}$ 
$\sec ^{-1}[6]$. This data indicates that Bau-Bau Watershed Area has been seriously degraded due to forested land use change. It is therefore important to take approriate conservation efforts to ensure that this watershed area will be used in sustainable manner. It is also important te explore possible fund resources through Payment for Environmental Services.

\subsection{Economic Value of Domestic Use of Water}

Clean water is a basic need for human beings. The use of water is different between one to others which depend on the need of the users. Thus, water consumption is diffrent between one region to others which relies on the extent of individual need of clean water in each. A region with high population numbers has a tendency to consume much more clean water than less population number [14]. A number of water consumption by local community of Baubau Wonco Watershed is a total need of clean water for domestic use. Baubau Wonco Watershed has served hydrological environmental services for local community of Baubau City both in a form of surface water and ground water as sources of clean water.

This research found that a total volume of water consumption for domestic use is $6.163 .488,50 \mathrm{~m}^{3}$ year ${ }^{-1}$ which consumpted by 18.950 households. Based on water consumption, using a formula 2, which clean water price is $\mathrm{Rp} .6 .500 \mathrm{~m}^{-3}$, resulting in the economic value of water consumption for domestic use as $\mathrm{Rp}$ 40.062.668.750 year $^{-1}$. This result is relatively high compared to consumption of domestic water in other regions, for example domestic water consumption of local people in surrounding catchment forests of Baini Village of Konawe District only achieved $278,55 \mathrm{~m}^{3}$ with total population 445 people [9]. A relative high domestic water consumptions has a consequency to the hydrological conditions of Baubau Wonco Watershed as well as to the conservation efforts that should be made by watershed stakeholders. A high domestic water need can lead to water shortage, especially in the summer session. On the other hand, a lot of water is wasted through run off during the rainy season. It is therefore, source of available funds for catchment forest conservation efforts that will mostly be implemented by upstream community need to be explored. The available fund sources can be in a form of Payment for Environmental Services both from Baubau Wonco Watershed's community and local/ central government as well as from international community.

\subsection{Economic Value of Water for Agricultural Use}

Environmental economic primarily deals with a valuation of natural resources and environment. Before conducting valuation, there is a need to determine kinds of economic values that can be given to the those natural resources and environment. The analysis of economic value of water used for agricultural activity focusing on irrigated water for paddy field. Irrigated water is water from the river of Baubau Wonco Watershed which is streamed to paddy fields of local farmers in order to maintain water balancing of the paddy fields and to increase of its productivity.
Paddy fields within DAS Baubau Wonco cover about 100 Ha. There are 32 local farmers cultivate this annual crop for fulfilling their daily need and selling to the local market [1]. According to Central Government Decree by the year 1999 stated that local farmers can share budgets for maintaining facilities of irrigation in the tertier pipeline units through a payment for irrigation water by water user of local farmer association [14]. Furthermore, realocation of irrigated water for non agricultural use can bring about negative impacts to village economic conditions, a decrease of irrigated water volume, then a decline of a crop width and causing a decrease of food productivity and a loss of livelihood of local farmers (Rosegrant and Ringler, 1998) [14].

Nowadays, irrigated water users in Baubau City tend to increase and lead to an increase in water demands. In the other words, water resource is becoming more competitive resource. To this end, valuation of irrigated water is crucial in order to determine amount of budgets that can be shared by local farmers.

This study attemped to extrapolate the economic value of irrigated water using Productivity Function Method. This method is used through the analysis of costs that has been spended and revenues that has been obtained by local farmers from paddy product. There is also a need to calculate an average of irrigated water use. Using this method, local farmers can then calculate the economic value of irrigated water which has been used for increasing their paddy crop productivities.

The cost analysis shows that the average cost that has been spended by local farmers in producing paddy crop achieves Rp.9.080.000 year ${ }^{-1}$. This value multiplies by 32 people (number of local farmers cultivating paddy crop) results in Rp 290.560.000 year $^{-1}$. Whereas the total revenue obtains Rp. 585.000.000 year $^{-1}$, with an average revenue of each farmer is Rp.18.281.250 year $^{-1}$. So, the total income of paddy crop farmers is Rp. 294.440.000 year ${ }^{-1}$.

[15] explained that accounting irrigated water costs should be clearly determined the function of production which explains conseptual relationship between inputs and outputs, for example, in order to product paddy crop, there are four inputs that involved namely : capital, labour, such natural resources as land and irrigated water. To this point, economic value of water is a difference between the total economic value of paddy crop and the total spended costs of the three kinds of inputs.

The study found that an average water consumption for irrigation is $25,55 \mathrm{~m}^{3} \mathrm{ha}^{-1}$ dan the total volume of water consumption for irrigation is $2.555 \mathrm{~m}^{3} \mathrm{ha}^{-1}$. Paddy crop is harvested once a year. The economic value of water achieves Rp. 30.199.167 ha $^{-1}$ year $^{-1}$. This is relatively high compared to an economic value of irrigated water in Kampar Watershed that obtains $1.483 .500 \mathrm{ha}^{-1}$ year $^{-1}$ [4], while an economic value of irrigated water in Van Der Wijce tirrigation, Sleman Regency obtains $1.388 .742 \mathrm{ha}^{-1}$ year $^{-1}$ [15]. The study found that the difference level of economic value of irrigated water between the regions caused by both the difference acreage of the paddy fields and its productivity as well as the difference 
method of valuation.

Irrigated water is mostly assumed as free commodity by the farmers so that it can be freely used. This assumption can create problem with respect to the maintenance of irrigation facilities. This is due to lack of awareness and fund to maintain those facilities. The research has determined economic value of irrigated water within Baubau Wonco Watershed. This can lead to the arising awareness of local government and farmers to collaborate in developing a model of payment for environmental services that have been provided by catchments forests. The second year study will attempt to explore an appropriate model than can facilitate Baubau Wonco's stakeholders to share resources and funds for protecting the watershed from further degradation.

\section{Conclusions}

a. There are various major economic and environmental importance of Baubau Wonco Watershed supported by catchment forests namely: Water for domestic, industrial and agricultural use (irrigation); Erosion, flooding and land slide hazard prevention, wildlife habitat, and ecotourism.

b. As the first year study attempted to predict economic valuation of water for domestic and agricultural uses. Economic value of water provided by watershed area for domestic used obtains Rp. 40.062.668.750 year $^{-1}$, while for agricultural use achieves Rp. 30.199.167 $\mathrm{ha}^{-1}$ year $^{-1}$.

c. These economic values are relatively high compare to other regions and it will bring a consequency to serious

d. conservations efforts. Otherwise, high environmental costs will be much more higher than determined economic values as found in this study to restore the ecosystem of the watershed.

e. The second year study will be intended to analyze the economic value of water for industrial use, and the economic value of catchment forest's functions to prevent both community and watershed ecosystem from erosion, flooding and landslide hazards. Thus, the Total Economic Value of the hydrological environmental services can be calcullated. A proper model of downstream-upstream mechanism of a payment for hydrological environmental services will be explored and developed at the second year of the study.

\section{Acknowledgment}

The grateful thanks are delivering to the Head of Board Planning Agency of Baubau City that has provided supports for the planning and implementation of the research activities. We also thanks to the Directore of Central Higher Education Office of Ministry of Research and Technology and Higher Education of Republic Indonesia that has provided funds for the implementaion of this research.

In particular thanks goes to The Rector of Halu Oleo University for his legal and moral supports in implementation and compliance of this research. Many thanks also go to the head of Research and Community Service Center of Halu Oleo University for their supports in administeration matter and process. Last but not the least, a very grateful thank goes to the research team for their dedication and time management so that this research can be accomplished on schedule.

\section{References}

[1] Biro Pusat Statistik Kota Baubau, 2011. Baubau City in Numbers. BPS. Baubau.

[2] Brand, D. 2002. Investing in the Environmental Services of Australian Forest. In: Pagiola, S., Landell-Mills, N. And Bishop, J (Eds). (2002) Selling Forest Environmental Sevices; Market-Based Mechanism for Conservation and Development, London. Pp234-245.

[3] Isnin, M., Basri., H., and Romano, 2012. Economic Value of Water availability of Krueng Jreu Sub Watershed Aceh Besa Regency. Faculty of Agriculture, Syiahkuala University. Banda Aceh.

[4] Januaris, 2004. The estimation of Economic Value of Irrigated Water to Support Agricultural Development in Kampar Watershed. IPB. Bogor.

[5] Kasim, S., A.M..Kandari., Kahirun., 2007. Study on Characteristics of Baubau Wonco Watershed. Faculty of Agriculture, Halu Oleo University. Kendari.

[6] Kasim, S., Midi. L., 2012. Impacts of Forested Land Use Changes on the Hydrological Functions of Baubau Wonco Watershed. Proceeding of International Seminar on CRISHU Forum October 17th 2013.

[7] Kasim, S., Midi. L.,. 2013. Agroforestry System as Vegetative Conservation Method for Land Use Development in Baubau Wonco Watershed. Halu Oleo University. Kendari.

[8] Kasim, S., Midi, L., and Sarlina, 2014. Valuation of Hydrological Environmental Services of Production Forest Area of Baini Village, Sampara Subdistrict, Konawe Regency. Faculty of Forestry and Environmental Science, Halu Oleo University. Kendari.

[9] Kasim, S., Agustina, S., and Miduanto, 2014. Valuation of Hydrological Environmental Services of Watu Mate Protected Forest, Waworaha Village, Lasolo Subdistrict of South Konawe Regency. Faculty of Forestry and Environmental Science, Halu Oleo University, Kendari.

[10] Merryna, A. 2009. Willingness To Pay Analysis of Local Community of Cirahab Sub Watershed. Economy and Environmental Department of ITB. Bandung.

[11] Meteorology Station of Betoambari, 2013. Recent Climatic Report of Baubau City. Baubau.

[12] Moore I.D. and J.P. Wilson. 1992. Length-slope factors for the revised universal soil loss equation: Simplified method of estimation. Journal of Soil and Water Conservation. 47(5):423-428.

[13] Panhalkar S, 2011. Land Capability Classification for Integrated Watershed Development by a Applying Remote Sensing and GIS techniques. Journal of Agricultural and Biological Science. VOL. 6, NO. 4, APRIL 2011, Pages 46-55. ISSN 1990-6145. Asian Research Publishing Network (ARPN). 
[14] Sumaryanto, 2006. An Increase of Irrigated Water Efficiency Through an Implemetation of Environmental Tax based on Economic Value of Irrigation. The Center of Social, Economy and Policy Analysis of Agriculture. Bogor.

[15] Syaukat, Y., dan Siwi, N., A., A, 2009. An Estimation of Economic Value of Irrigated Water at Paddy Field Farm, Vab Der Wijce Irrigation Area of Sleman Regency, Yograkarta. Jurnal Ilmu Pertanian Indonesia. Yogyakarta.

[16] Wilson J. P. and J. C. Gallant. 2000. Terrain Analysis: Principles and Applications. John Wiley and Sons, New York. pp. 87-131.
[17] Winrock International, 2004. Financial Incentives to Communities for Stewardship of Environmental Resources; Feasibility Study. Winrock International, 621 North Kent Street, Suite 1200 Arlington, Virginia 22209 USA. www.winrock.org, $50 \mathrm{pp}$.

[18] Zahabu, E., Malimbwi R.E., and Ngaga, Y.M. 2005. Payment for Environmental Services as Incentive Opportunities for Catchment Forest Reserves Manaement in Tanzania. Community Carbon Organization. 